\title{
Chronic spontaneous urticaria treated with omalizumab: what differentiates early from late responders?
}

\author{
Allergology clinic, Clinica San Carlo, Paderno Dugnano, Milan, Italy
}

\author{
KEY WORDS \\ Chronic Urticaria; omalizumab; biomarkers; IgE; D-dimer; therapy.
}

\author{
Corresponding author \\ Riccardo Asero \\ Allergology clinic \\ Clinica San Carlo \\ via Ospedale 21 \\ 20037 Paderno Dugnano, Milan, Italy \\ E-mail: r.asero@libero.it
}

\section{Doi}

10.23822/EurAnnACI.1764-1489.147

To the editor,

Omalizumab is the first choice treatment for severe Chronic Spontaneous Urticaria (CSU) patients who are unresponsive to second-generation antihistamines even at higher than licensed dose (1). The drug is effective in about $85 \%$ of patients, inducing a dramatic drop in UAS-7 levels. The clinical effect can be very rapid (in about $70 \%$ of patients, the so-called early or fast responders, the effect may appear as early as 3-5 days after the first administration), or slow (in about 15\% of patients, the so-called late or slow responders, 3-4 months of treatment are needed to see a benefit). The drug is ineffective in the remaining $15 \%$ (2). Several recent studies have shown the association between elevated baseline total $\mathrm{IgE}$ levels and a positive response to omalizumab, with non-responders showing significantly lower IgE (3-5). A possible "auto-allergic" pathogenesis mediated by $\mathrm{IgE}$ specific for self-proteins may reasonably explain a rapid response to omalizumab in some patients with CSU $(6,7)$. In contrast, the reasons why a proportion of patients take months to respond to the drug are less clear. This subpopulation might coincide with patients showing an IgG-mediated autoimmune process able to activate mast cells and basophils via the high affinity IgE receptor, either directly (by IgG-
anti-FceRI) or indirectly (by IgG directed against receptor-bound $\operatorname{IgE})(8,9)$. In this case, the effect of omalizumab would rely on the down-regulation of IgE receptors, a process that would take some months (10). From the clinical point of view, patients showing a rapid or slow response to omalizumab have not been compared so far. The present study investigated the clinical and serological features in these two subsets of CSU patients.

One hundred and thirty patients (M/F: 53/77; mean age: 50,6 years (range 13-89 years)) with severe CSU (UAS-7 > 30) unresponsive to second generation antihistamines at any dosage and successfully submitted to treatment with omalizumab $300 \mathrm{mg} /$ month for at least 3 months were studied. Based on their response to Omalizumab, patients were classified as early responders (drop of at least $50 \%$ of UAS-7 from baseline level already 1 month after the first administration; $\mathrm{n}=108$ ) and late responders (no appreciable clinical effect one month after the first administration, but drop of at least $50 \%$ of baseline UAS-7 after 3 months of treatment; $\mathrm{n}=22$ ). Age, sex, disease duration, and several baseline clinical parameters including ESR, CRP, thyroid autoimmunity, total IgE , D-dimer, and atopic status (as assessed by SPT with a large panel of commercial extracts of both seasonal and perennial respiratory allergens) were compared between 
the two subsets. The Chi-Square test with Yates' correction, the two-tailed Student's t-test, or the Mann-Whitney non-parametric test were used where appropriate. Probability values less than $5 \%$ were regarded as statistically significant. The internal review board approved the study, and all the patients signed an informed consent to use their clinical data in an anonymous form. The study subpopulations are compared in table I. The two groups did not differ in gender, mean age, disease duration, atopic status, inflammation markers, and thyroid autoimmunity. In contrast, early responders showed a significantly higher proportion of patients showing elevated $(>100 \mathrm{UI} / \mathrm{ml})$ baseline total $\operatorname{IgE}(67 \%$ vs $33 \%$, respectively; $\mathrm{p}<0.05)$. Of those showing elevated total $\operatorname{IgE}$ at baseline, only 16/41 (39\%) and 2/5 (40\%) were atopic among early and late responders, respectively. Although median total $\mathrm{IgE}$ levels were much higher among early responders (181 UI/ml vs 45 $\mathrm{IU} / \mathrm{ml}$ for early and late responders, respectively), probably due to the small number of late responders the difference between the two subgroups did not reach the statistical significance.

To the best of our knowledge, this is the first study comparing the clinical features of the two specific subsets of CSU patients responding to anti-IgE therapy, namely the early and late responders. The two subsets of omalizumab responders were virtually identical with the only difference of a much larger proportion of patients showing elevated $\operatorname{IgE}$ levels in the early responders group. This observation is in keeping with previous studies showing the direct relationship between elevated IgE levels and the response to anti-IgE treatment in the general CSU population (3-5). It is conceivable that in these

Table I - Clinical and serological characteristics of patients showing a prompt or late response to omalizumab.

\begin{tabular}{|c|c|c|c|}
\hline & $\begin{array}{l}\text { Early responders } \\
(\mathbf{n}=108)\end{array}$ & $\begin{array}{l}\text { Late responders } \\
(\mathrm{n}=22)\end{array}$ & $\mathbf{p}$ \\
\hline $\mathrm{M} / \mathrm{F}$ & $44 / 64$ & $9 / 13$ & NS \\
\hline Mean age (years) & 49,7 & 54,8 & NS \\
\hline $\begin{array}{l}\text { Median disease } \\
\text { duration in months } \\
\text { (range) }\end{array}$ & $12(2-600)$ & $10,5(2-300)$ & NS \\
\hline Atopic status (\%) & $30(27 \%)$ & $9 / 22(41 \%)$ & NS \\
\hline $\begin{array}{l}\text { Thyroid } \\
\text { autoimmunity (\%) }\end{array}$ & $20 / 98(20 \%)$ & $3 / 21(14 \%)$ & NS \\
\hline $\begin{array}{l}\text { D-dimer } \\
>500 \mathrm{ng} / \mathrm{ml}\end{array}$ & $42(39 \%)$ & $9 / 21(43 \%)$ & NS \\
\hline $\begin{array}{l}\text { Total IgE } \\
>100 \mathrm{IU} / \mathrm{ml}\end{array}$ & $41 / 61(67 \%)$ & $5 / 15(33 \%)$ & $<0.05$ \\
\hline Median IgE level & $181(9-1139)$ & $45(5-1000)$ & NS \\
\hline $\begin{array}{l}\text { Elevated } \\
\text { CRP or ESR }\end{array}$ & $24(22 \%)$ & $4(18 \%)$ & NS \\
\hline
\end{tabular}

patients elevated total $\operatorname{IgE}$ may mirror the predisposition to synthesize autoreactive $\operatorname{IgE}$ antibodies that the anti-IgE mAb rapidly binds and eliminates from the circulation. It has also been shown that omalizumab is able to bind IgE fixed to the high affinity receptor and to detach them (11), which leads (in a long term) to a down-regulation of the receptor. In patients showing a slow response to omalizumab it is possible that this latter mechanism of action is the most important. In effect, a very recent study seems to suggest that the contemporary presence of IgE and IgG-mediated autoimmunity (particularly against the high affinity $\mathrm{IgE}$ receptor) may slow down the clinical response to the drug (12).

\section{Conflict of interests}

The author declares that he has no conflict of interests.

\section{References}

1. Zuberbier T, Aberer W, Asero R, et al. The EAACI/GA²LEN/ $\mathrm{EDF} / \mathrm{WAO}$ guideline for the definition, classification, diagnosis and management of urticaria. Allergy 2018;73(7):1393-1414.

2. Zhao ZT, Ji CM, Yu WJ, et al. Omalizumab for the treatment of chronic spontaneous urticaria: A meta-analysis of randomized clinical trials. J Allergy Clin Immunol 2016;137(6):1742-1750.

3. Straesser MD, Oliver E, Palacios T, et al. Serum IgE as an immunological marker to predict response to omalizumab treatment in symptomatic chronic urticaria. J Allergy Clin Immunol Pract 2018;6(4):1386-1388.

4. Ertas R, Ozyurt K, Atasoy M, Hawro T, Maurer M. The clinical response to omalizumab in chronic spontaneous urticaria patients is linked and predicted by IgE levels and their change. Allergy 2018;73(3):705-12.

5. Weller K, Ohanyan T, Hawro T, et al. Total IgE levels are linked to the response of chronic urticaria patients to omalizumab. Allergy 2018;73(12):2406-2408.

6. Schmetzer O, Lakin E, Topal FA, et al. IL-24 is a common and specific autoantigen of $\mathrm{IgE}$ in patients with chronic spontaneous urticaria. J Allergy Clin Immunol 2018;142(3):876-882.

7. Cugno M, Asero R, Ferrucci $S$, et al. Elevated IgE to tissue factor and thyroglobulin are abated by omalizumab in chronic spontaneous urticaria. Allergy 2018;73(12):2408-2411.

8. Grattan CEH, Francis DM, Hide M, Greaves MW. Detection of circulating histamine releasing autoantibodies with functional properties of anti IgE in chronic urticaria. Clin Exp Allergy 1991;21(6):695-704.

9. Hide M, Francis DM, Grattan CEH, Hakimi J, Kochan JP, Greaves MW. Autoantibodies against the high-affinity IgE receptor as a cause of histamine release in chronic urticaria. $\mathrm{N}$ Engl J Med 1993;328(22):1599-604.

10. Kaplan AP, Gimenez-Arnau AM, Saini SS. Mechanisms of action that contribute to efficacy of omalizumab in chronic spontaneous urticaria. Allergy 2017;72(4):519-533.

11. Maggi L, Rossettini B, Montaini G, et al. Omalizumab dampens type 2 inflammation in a group of long-term treated asthma patients and detaches IgE from FceRI. Eur J Immunol 2018;48(12):2005-2014.

12. Asero R, Marzano AV, Ferrucci S, Lorini M, Carbonelli V, Cugno $\mathrm{M}$. Co-occurrence of $\operatorname{IgE}$ and $\operatorname{IgG}$ autoantibodies in patients with chronic spontaneous urticaria. Clin Exp Immunol 2020;200(3):242-249. 